\author{
Jurnal E-KOMTEK (Elektro-Komputer-Teknik) \\ Vol. 4, No. 2 (2020) pp. 168-183 \\ https://jurnal.politeknik-kebumen.ac.id/index.php/E-KOMTEK \\ p-ISSN : 2580-3719 e-ISSN : 2622-3066
}

\title{
Sistem Monitoring berbasis Internet of things pada Suhu dan Kelembaban Udara di Laboratorium Kimia XYZ
}

\author{
Andi Yusika Rangan ${ }^{1 *}$, Amelia Yusnita ${ }^{2}$, Muhammad Awaludin ${ }^{3}$ \\ ${ }^{1}$ Teknik Informatika, STMIK Widya Cipta Dharma, Indonesia, 75121 \\ 2Sistem Informasi, STMIK Widya Cipta Dharma, Indonesia, 75121 \\ 3Teknik Informatika, STMIK Widya Cipta Dharma, Indonesia, 75121 \\ *E-mail : andi@wicida.ac.id \\ Doi : https://doi.org/10.37339/e-komtek.v4i2.404
}

Diterbitkan oleh Politeknik Dharma Patria Kebumen

\section{Info Artikel \\ Diterima :}

Diperbaiki :

Disetujui :

\begin{abstract}
ABSTRAK
Laboratorium kimia digunakan untuk eksprimen riset ilmiah menggunakan bahan atau zat kimia yang sensitif terhadap perubahan suhu dan kelembaban. Karenanya diperlukan pengecekan suhu dan kelembaban untuk menjaga reaksi kimia yang membahayakan. Penelitian bertujuan membangun sistem monitoring berbasis Internet of things pada suhu dan kelembaban udara di laboratorium kimia XYZ sehingga pemantauan suhu dan kelembaban udara bisa dilakukan secara realtime. Metode pengembangan sistem yang digunakan adalah prototype pada metode ini proses pengembangan sistem, penguna dan pengembang sistem berkomunikasi selama proses pembuatan sistem sehingga hasilnya sesuai kebutuhan. Sistem monitoring berbasis internet of things memungkinkan pengecekan suhu dan kelembaban secara realtime. Perangkat yang digunakan adalah Sensor DHT11, sebagai pendeteksi suhu dan kelembaban udara, mikrokontroler NodeMCU ESP8266, sebagai pengolah data sehingga deteksi sensor DHT11 dapat ditampilkan pada website. Software yang digunakan Arduino Integrated Development Environment, XAMPP, dan Sublime. Dengan menerapkan sistem berbasis internet of things pemantauan suhu dan kelembaban laboratorium dapat diakses secara realtime.

Kata kunci: Internet of Things; Sensor; Mikrokontroler; Prototype
\end{abstract}

\begin{abstract}
Chemical laboratories are used for scientific research experiments using substances or chemical substances that are sensitive to changes in temperature and humidity. Therefore it is necessary to check temperature and humidity to prevent harmful chemical reactions. The research aims to build a monitoring system based on the Internet of things on temperature and humidity in the $X Y Z$ chemical laboratory so that monitoring of temperature and humidity can be done in real time. The system development method used is a prototype in this method the system development process, system users and developers communicate during the system creation process so that the results are as needed. An internet of things-based monitoring system allows real-time temperature and humidity checks. The device used is the DHT11 sensor, as a detector for temperature and humidity, and the NodeMCU ESP8266 microcontroller, as a data processor so that DHT11 sensor detection can be displayed on the website. The software used by the Arduino Integrated Development Environment, XAMPP, and Sublime. By implementing an internet of things-based system, laboratory temperature and humidity monitoring can be accessed in real time.
\end{abstract}

Keywords: Internet of Things; Sensor; Microcontroller; Prototype

Alamat Korespondensi : Jl. Letnan Jenderal Suprapto No.73 Kebumen, Jawa Tengah, Indonesia 55431 This work is licensed under a Creative Commons Attribution-NonCommercial 4.0 International License. 


\section{PENDAHULUAN}

Laboratorium merupkan tempat untuk melakukan riset-riset atau eksperimen ilmiah. laboratorium kimia adalah ruangan khusu yag dilengkapi dengan peralatan dan fasilitas yang digunakan percobaan-percobaan kimiawi. Laboratorium harus memenuhi syarat-syarat keamana seperti kestabilan suhu dan kelembaban ruangan karena bahan-bahan atau zat-zat kimia yang sensitif terhadap perubahan suhu dan kelembaban ruang. Oleh karena itu perlu dilakukan pengecekan kondisi keadaan suhu dan kelembaban ruangan secara berkala serta mengantisipasi jika ada perubahan dari suhu dan kemebapan ruangan dengan pengadaan pendingin ruangan dan kipas.

Pada penelitian "sistem Monitoring suhu, kelembaban dan gas Aminia pada kandang sapi berbasis teknologi Internet of Things (IoT)" berfokus pada menciptakan sistem monitoring yang mengirim data tentang temperature,kelembaban, dan gas ammonia dari sebuah kandang sapi perah. Sistem ini juga memberikan notifikasi dan rekomendasi kepada pemilik untuk melakukan aksi tertentu berdasarkan data yang didapatkan dari kandang sapi tersebut. Sistem ini terdiri atas tiga komponen utama yaitu perangkat monitoring web server dan aplikasi pada perangkat bergerak. Selanjutnya, perangkat monitoring terdiri aras sebuah mikrokontroller, sensor DHT22, MQ-135 and ESP266. Mikokontroller mengirimkan datar ke web server dan perangkat bergerak secara kontinu untuk memberitahu keadaan kandang [1].

Pada penelitian "Monitoring Suhu dan Kelembaban Menggunakan SMS Gateway Pada Proses Fermentasi Tempe Secara Otomatis Berbasis Mikrokontroler“. Pengontrolan sistem dilakukan oleh Mikrokontroler Arduino UNO yang mempunyai input berbentuk sensor sht11, sensor ini akan mendeteksi suhu dan kelembaban yang berada dalam Inkubator dan menampilkannya pada LCD dan memonitoring melalui SMS Gateway [2].

Pada Penelitian “Sistem Monitoring Suhu Laboratorium Komputer Menggunakan SMS Berbasis Arduino". bertujuan membuat alat yang dapat memantau suhu laboratorium komputer secara berkelanjutan. Alat ini dibuat menggunakan Arduino UNO sebagai pemroses data, sensor suhu LM35 sebagai pendeteksi suhu dan SMS sebagai media monitoring [3].

Pada penelitian "Sistem Pemantauan Suhu dan Kelembaban Inkubator Telur Melalui Jaringan Global System For Mobile Berbasis Short Message Service". Berfokus mengaplikasikan dan mengetahui ketepatan SMS sebagai media untuk memantau, keadaan suhu dan kelembaban pada inkubator telur. Penelitian ini menggunakan modul GSM Icomsat V1.1 yang dihubungkan dengan data logger shield dan arduino uno [4]. 
Sedangkan penelitian ini berfokus pada pembuatan Sistem monitoring berbasis internet of things memungkinkan pengecekan suhu dan kelembaban secara realtime. Perangkat yang digunakan adalah Sensor DHT11, sebagai pendeteksi suhu dan kelembaban udara, mikrokontroler NodeMCU ESP8266, sebagai pengolah data sehingga deteksi sensor DHT11 dapat ditampilkan pada website.

Tujuan yang ingin dicapai dari penelitian ini adalah merancang alat yang digunakan dalam monitoring suhu dan kelembaban secara realtime dimanapun dengan menghubungkan alat pendeteksi suhu dan kelembaban dengan web server mengunkan jaringan internet serta menerapan internet if things dalam memonitoring suhu dan kelembaban ruangan. Pengembangan sistem yang digunakan adalah metode prototype. Metode prototype digunakan untuk menyamakan persepsi dan pemahaman mengenai sistem yang dibangun, sehingga dihasilkan sistem yang sesuaia dengan kebutuhan pengguna.

\section{MATERIAL DAN METODE}

\subsection{Material}

a. Sistem Monitoring

Sistem monitoring adalah pengumpulan data yang dilakukan secara realtime untuk mengamati suatu data daru alat ukur oleh manusia dimanapun dan kapanpun [5].

b. Internet Of Things

Diperkenalkan pada tahun 1999 oleh Kevin Ashto, IoT adalah menghubungkan berbagai objek untuk melakuakn kegiatan komputasi secara cerdas memanfaatkan jaringan internet. Pengunaan IoT meningkatkan pengunaan internet sehari-hari karena setiap objek akan terintergrasi secara terdistribusi dimana setiap perangkat ataupun software yang dihasilkan akan meningkatkan kualitas hidup. Hal ini menarik perhatian penelitan dan pratisi bidang teknologi [6].

Internetof Things (IoT) adalah struktur di mana objek, orang disediakan dengan identitas eksklusif dan kemampuan untuk pindah data melalui jaringan tanpa memerlukan dua arah antara manusia ke manusia yaitu sumber ke tujuan atau interaksi manusia ke computer [7].

\section{c. Laboratorium Kimia}

Laboratorium merupakan salah satu tempat melakukan uji coba dan penelitian bebagai reaksi kimia dari bahan-bahan kimia. Untuk terlaksananya kegiatan penelitian yang aman 
diperlukan berbagai fasilitas-fasilitas seperti air, gas, listrik, fasilitas keselamatan kerja dan lainlain [8].

\section{d. Web Server}

Webserver adalah software yang diciptakan pada tahun 1980an, berfungsi menerima permintaan dari client dalam bentuk HTTP atau HTTPS yang terhubung dengan laman website. permintaan client melalui browser seperti firefox, chrome dan lain-lain [9].

\section{e. Mikrokontroler}

Mikrokontroler NodeMCU ESP8266 adalah sebuah platform IoT yang bersifat opensource. Terdiri dari perangkat keras berupa System OnChip ESP8266 dari ESP8266 buatan Espressif System, juga firmware yang digunakan, yang menggunakan bahasa pemrograman scripting Lua. Istilah NodeMCU secara default sebenarnya mengacu pada firmware yang digunakan dari pada perangkat keras development kit. Pengembangan kit karena modul ESP8266 mengintegrasikan GPIO, PWM (Pulse Width Modulation), IIC, 1-Wire serta Analog to Digital Converter atau ADC dalam 1 board. Board NodeMCU memiliki keunggulan yang kecil dengan panjang $4.83 \mathrm{~cm}$ disertai lebar board 2,54 cm dengan berat hanya 7 gram. Keunggulan lainny adalah memiliki fitur wifi dan firmware opensouce serta harga yang lebih murah jika dibandingkan dengan arduino uno. Board NodeMCU disajikan pada Gambar 1.

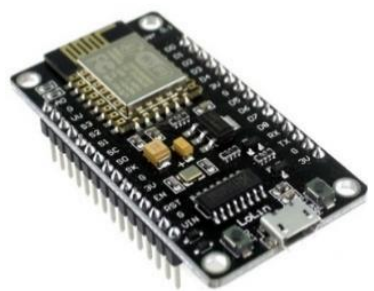

Gambar 1. Board NodeMCU

NodeMCU ESP8266-12E adalah otak kendali pada alat monitoring suhu dan kelembaban dimana bisa di akses secara oline mengunakan web berbasis ESP8266 yang disajikan pada

\section{Gambar 2.}

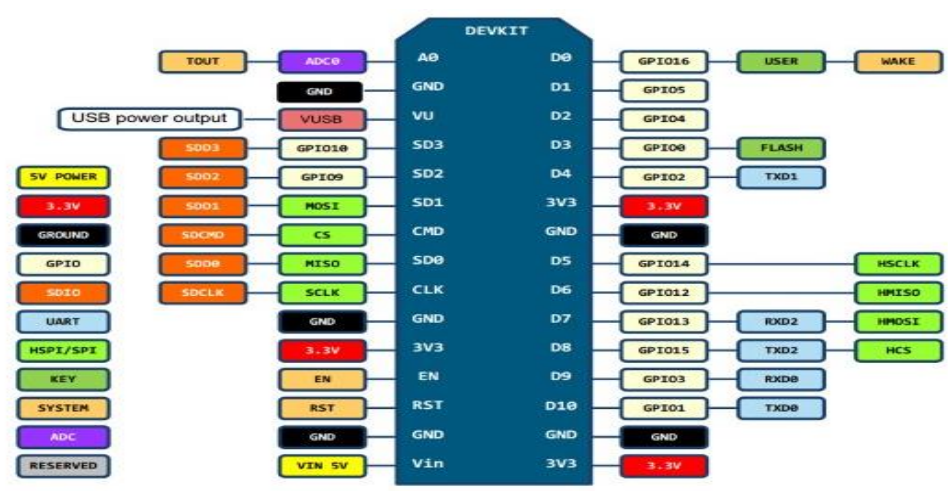

Gambar 2. Susunan Pin NodeMCU ESP8266 


\section{f. Sensor DHT11}

Sensor DHT11 adalah modul sensor yang berfungsi untuk mensensing objek suhu dan kelembaban yang memiliki output tegangan analog yang dapat diolah lebih lanjut menggunakan mikrokontroler. Sensor DHT11 pada umumya memiliki fitur kalibrasi nilai pembacaan suhu dan kelembaban yang cukup akurat. Penyimpanan data kalibrasi tersebut terdapat pada memori program OTP yang disebut juga dengan nama koefisien kalibrasi. Berikut adalah susunan pin sensor DHT11 yang disajikan pada Gambar 3.

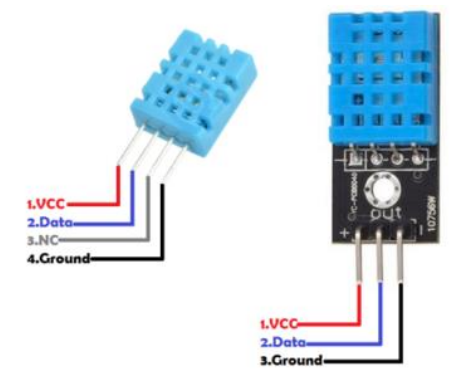

Gambar 3. Susunan pin sensor DHT11

Sensor DHT11 memiliki 2 versi, yatu versi 4 pin dan versi 3 pin. Tidak ada perbedaan karakteristik dari 2 versi ini. Pada versi 4 pin,. Pin 1 adalah tegangan sumber, berkisar antara 3V sampai 5V. Pin 2 adalalah data keluaran (output). Pin ke 3 adalah pin NC (normall y close) alias tidak digunakan dan pin ke 4 adalah Ground. Sedangkan pada versi 3 kaki, pin 1 adalah VCC antara 3V sampai 5V, pin 2 adalah data keluaran dan pin 3 adalah Ground.

\section{$2.2 \quad$ Metode}

Diagram penelitian disajikan pada Gambar 4.

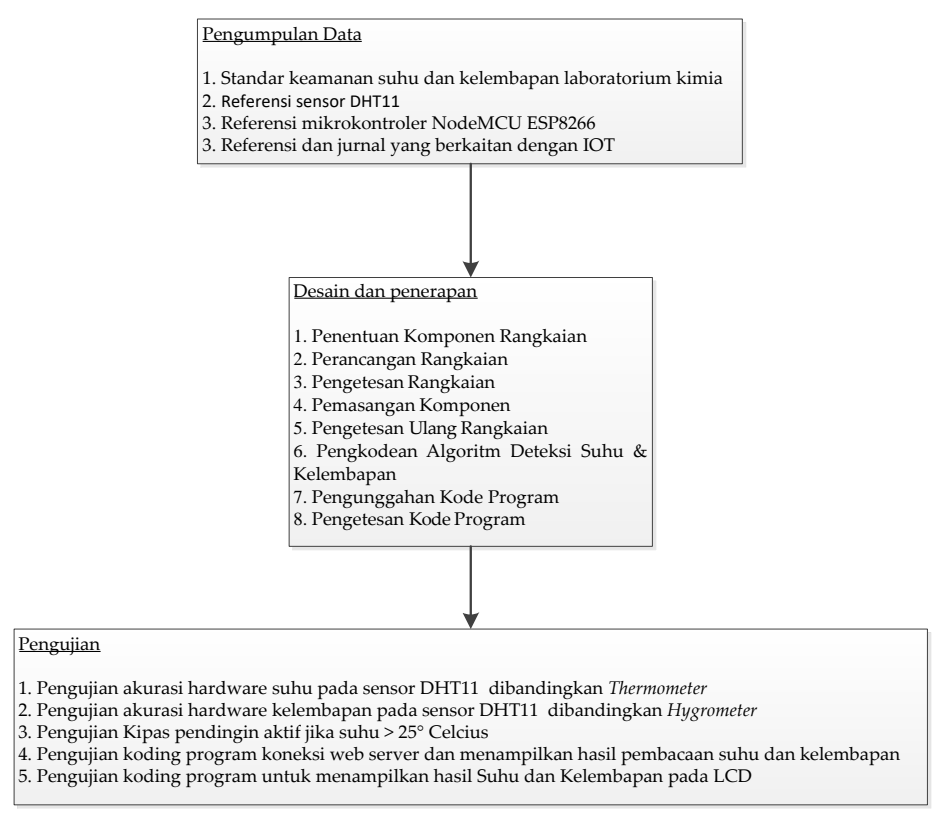

Gambar 4. Diagram Penelitian 
Prototipe adalah model fisik kerja sebuah sistem atau subsistem, prototipe berfungsi sebagai versi awal sistem atau komponen dari persyaratan mana yang diekstraksi dan yang mana versi selanjutnya didasarkan [10]. Metode ini mengharuskan selama proses pembangunan perangkat lunak terjadi interaksi antara pengembang dan pengguna perangkat lunak. Metode Prototyping disajikan pada Gambar 5.

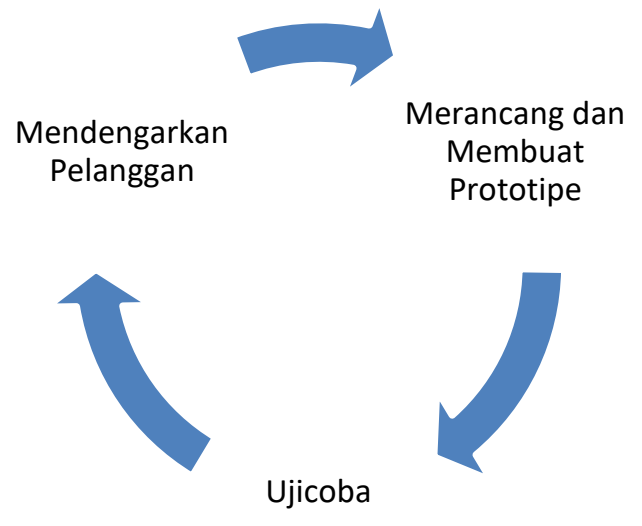

Gambar 5. Metode Prototyping

Tahapan metode prototype terdisi dari 3 tahapan sebagai berikut :

a. Mendengarkan Masukan Pelanggan

Pada bagian ini dilakukan pengumpulan data untuk dilakukan analisa untuk kebutuhan pembagunan sistem yang akan dibangun, bagaimana sistem yang berjalan dan harapannya terhadap sistem yang akan dibangun.

b. Desain dan Implementasi Prototipe

Pada bagian ini merancang desain sistem, menganalisa keutuhan sistem dan mengimplentasikan hasil rancangan dalam bentuk koding program sehingga mengahasilkan perangkat lunak yang diinginkan

c. Pengujian

Pada tahapan ini perangkat lunak yang dihasilkan dilakukan pengujian dengan metode yang sudah ditentukan baik blackbox, whitebox dan lain-lain

\section{HASIL DAN PEMBAHASAN}

\subsection{Mendengarkan Penguna}

Pada tahapan ini, interaksi antara pengembang dan penguna didapatkan informasi yang dibutuhkan dalam pengembangan perangkat lunak sebagai berikut : 


\section{a. Analisis Data}

Data yang dibutuhkan adalah data suhu dan data kelembaban udara, diman data tersebut dapat diperoleh dari sensor DHT11. Kemudian data-data ini akan tersimpan di dalam database dan akan ditampilkan langsung di laman website monitoring.

\section{b. Analisis Kebutuhan}

Untuk membangun alat monitoring ini dapa dibagi menadi kebutuhan perangkat lunak dan perangkat keras. untuk perangkat lunak yang dibutuhkan adalah software arduino IDE, Xampp, aplikasi browser dan sublime. Sedangakan perangkat keras yang dibutuhkan adalah NodeMCU ESP8266, Kipas Fan, Breadboard, Relay, LCD (Liquid Crystal Display), Sensor DHT11, Kabel Jumper.

\subsection{Merancang dan Membuat Prototipe}

Pada tahapan ini dilakukan perancangan dan pembuatan prototipe berdasarkan informasi dari penguna. berdasarkan hasil analisis maka dibuatlah dperancangan blok diagram blok diagram ini dibuat untuk merencanakan perangkat keras (hardware) sesuai dengan spesifikasi dan cara kerja dari sistem yang hendak dibuat sehingga diharapkan dapat mengefisiensi waktu, biaya, dan tenaga. Blok diagram sistem monitoring suhu dan kelembaban udara disajikan pada

\section{Gambar 6.}

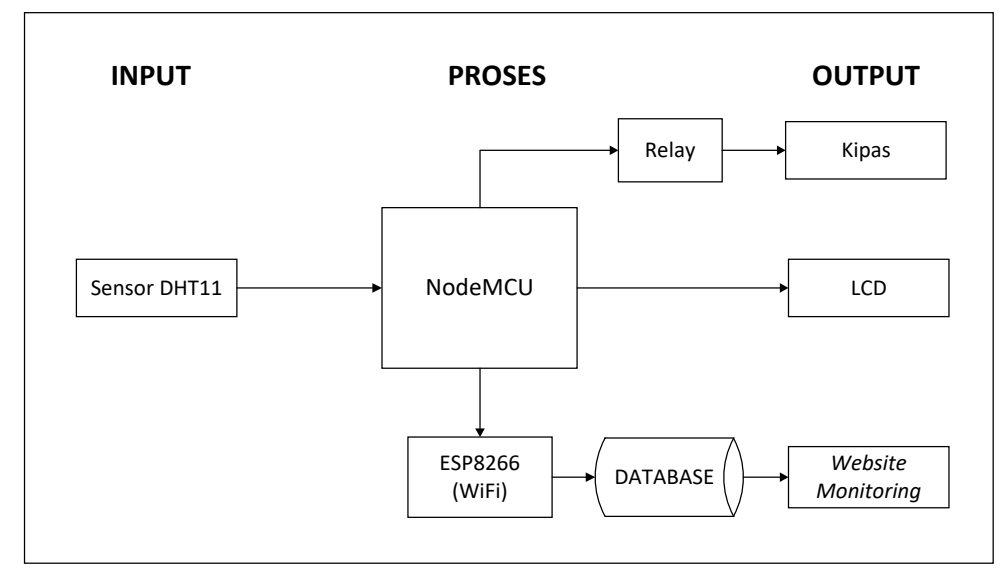

Gambar 6. Blok Diagram Sistem Monitoring Suhu dan Kelembaban Udara

Pada perancangan dari desain sistem monitoring suhu dan kelembaban udara pada laboratorium kimia berdasarkan gambar di atas. Sensor DHT11 mengukur suhu dan kelembaban udara yang ada pada laboratorium kimia, kemudian mikrokontroler NodeMCU ESP8266 memproses data sensor yang telah didapatkan dari sensor DHT11 yang kemudian data sensor tersebut ditampilkan melalui LCD (Liquid Crystal Display), terdapat ESP8266 yang terhubung ke 
NodeMCU yang berfungsi untuk koneksi ke jaringan WiFi yang kemudian data sensor DHT11 dikirim atau disimpan ke Database sehingga data sensor tersebut dapat ditampilkan melalui jarak jauh secara real time menggunakan Website Monitoring, dan terdapat relay yang berfungsi untuk menyambung dan memutus arus listrik pada kipas. Yang selanjutnya dilakukan adalah mendesain untuk flowchart sistem. Flowchart system disajikan pada Gambar 7.

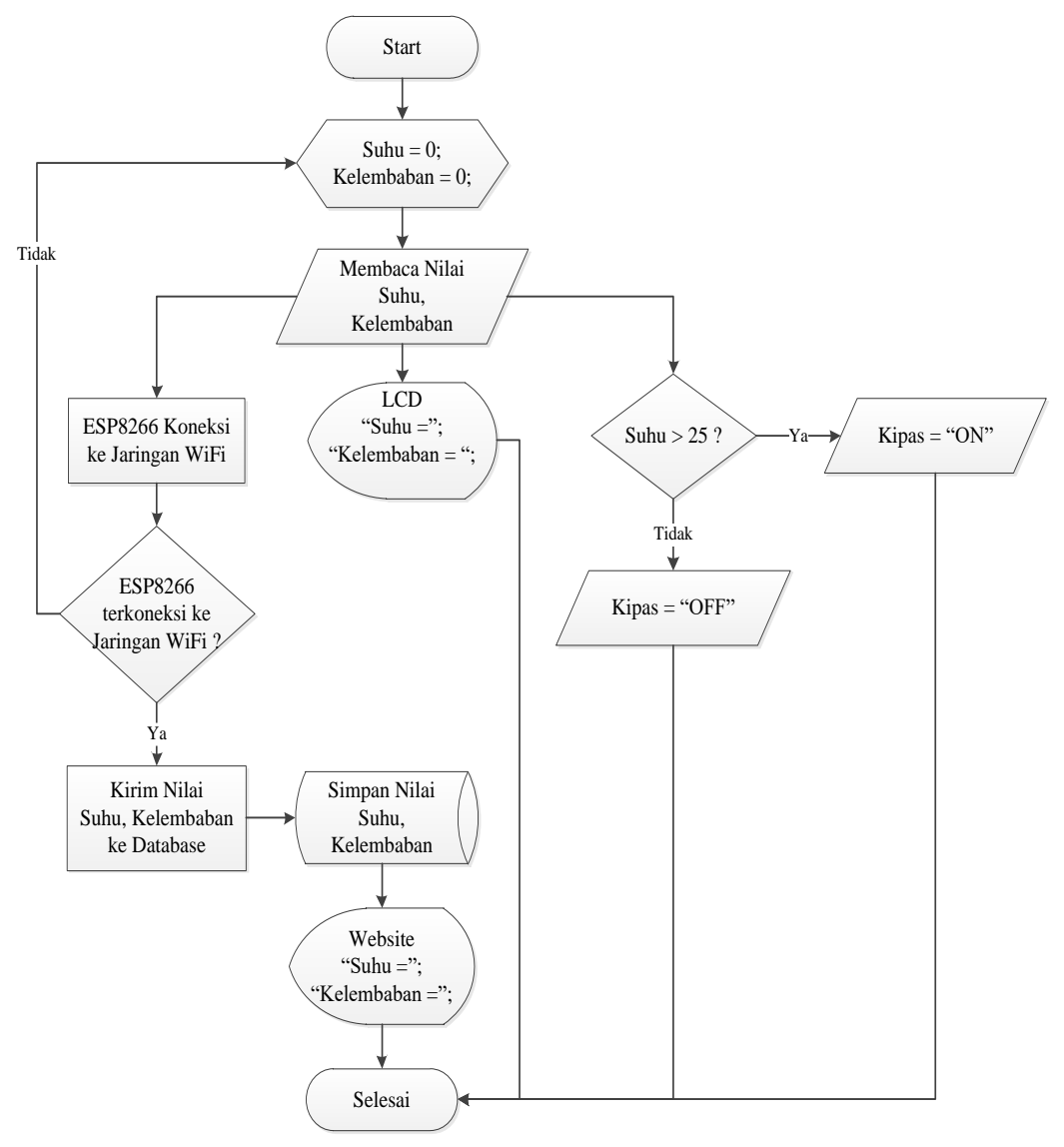

Gambar 7. Flowchart Sistem

Pada saat alat monitoring suhu dan kelembaban udara dalam keadaan menyala, yang pertama kali dilakukan adalah melakukan pengukuran suhu dan kelembaban udara. Hasil pengukuran ditampilkan berupa output yang ditampilkan melalui LCD (Liquid Crystal Display) dan Website Monitoring suhu dan kelembaban udara yang telah dibuat. Apabila suhu telah melebihi 25 derajat celcius maka sistem kontrol pendingin otomatis akan $O N$.

Selanjutnya adalah implementasi rancangan desain dengan melakukukan perakitan rangkaian alat monitoring suhu dan kelembaban. Rangkaian alat monitoring suhu dan kelembaban disajikan pada Gambar 8. 


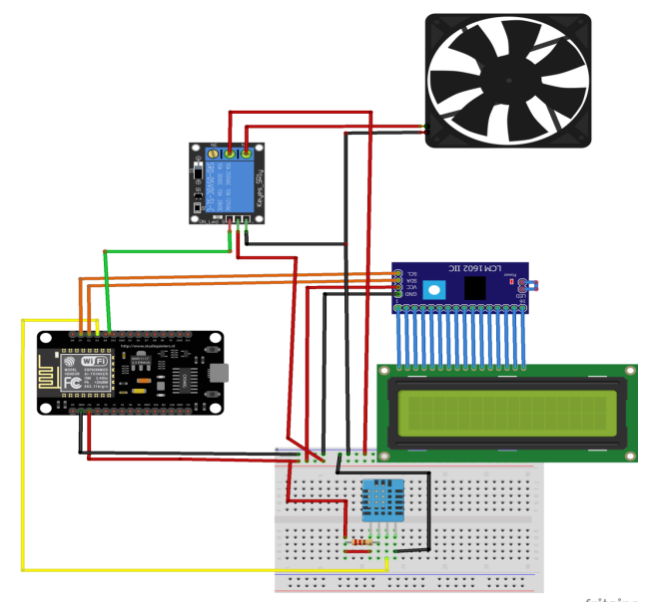

Gambar 8. Rangkaian Alat Monitoring Suhu dan Kelembaban

Perangkat keras atau hardware yang digunakan pada alat monitoring suhu dan kelembaban udara pada laboratorium kimia adalah sensor DHT11 yang merupakan sensor suhu dan kelembaban udara, NodeMCU ESP8266 yang merupakan mikrokontroler yang akan memproses data sensor DHT11 sehingga menjadi data output atau keluaran, kipas fan, relay, breadboard, LCD, dan kabel jumper.

Database yang dibuat menggunakan tabel yang telah disesuaikan dengan kebutuhan alat monitoring suhu dan kelembaban udara pada laboratorium kimia. File database ini digunakan untuk menyimpan data dan informasi hasil pengukuran suhu dan kelembaban udara pada laboratorium kimia. Tabel admin disajikan pada Tabel 1. Tabel monitoring disajikan pada Tabel 2.

Tabel 1. Tabel Admin

\begin{tabular}{lll}
\hline \multicolumn{1}{c}{ Nama Field } & \multicolumn{1}{c}{ Tipe Data } & \multicolumn{1}{c}{ Keterangan } \\
\hline Username & Varchar & $\begin{array}{l}\text { Username dari pengguna yang digunakan ketika } \\
\text { akan login website. }\end{array}$ \\
Password & Varchar & $\begin{array}{l}\text { Password pengguna yang digunakan ketika akan } \\
\text { login website. }\end{array}$ \\
Nama & Varchar & $\begin{array}{l}\text { Nama lengkap pengguna. } \\
\text { Nip }\end{array}$ \\
tanggal_lahir & Varchar & Nomor Induk Pegawai dari pengguna. \\
\hline
\end{tabular}

Tabel 2. Tabel Monitoring

\begin{tabular}{lll}
\hline \multicolumn{1}{c}{ Nama Field } & Tipe Data & \multicolumn{1}{c}{ Keterangan } \\
\hline Id & Bigint & Nomor urutan suhu dan kelembaban. \\
Suhu & Float & $\begin{array}{l}\text { Data suhu yang didapat dari hasil pengukuran sensor } \\
\text { DHT11. } \\
\text { kelembaban }\end{array}$ \\
Int & $\begin{array}{l}\text { Data kelembaban yang didapat dari hasil pengukuran } \\
\text { sensor DHT11. }\end{array}$ \\
tanggal_waktu & Timestamp & Tanggal dan waktu saat dilakukannya pengukuran. \\
\hline
\end{tabular}


Pembuatan website monitoring, pada laman website ini pengguna bias mengakses suhu dan kelembaban ruangan laboratorium.

\section{a. Tampilan Login}

Dibawah merupakan tampilan Halaman login website dengan memasukkan username dan password pengguna atau operator maka akan dapat mengakses websitemonitoring suhu dan kelembaban udara pada laboratorium kimia. Tampilan login disajikan pada Gambar 9.

\section{b. Tampilan Home}

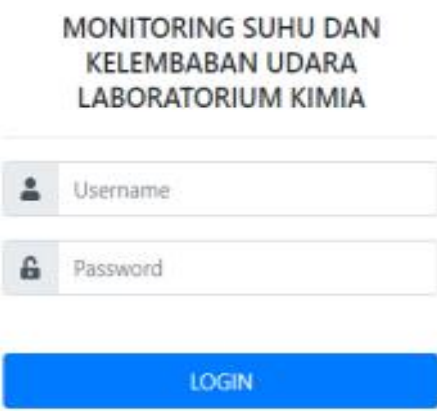

Gambar 9. Tampilan Login

Dibawah merupakan tampilan awal ketika login berhasil, dimana pada halaman ini terdapat data suhu dan kelembaban udara terkini yang tersimpan di dalam database. Tampilan home disajikan pada Gambar 10.

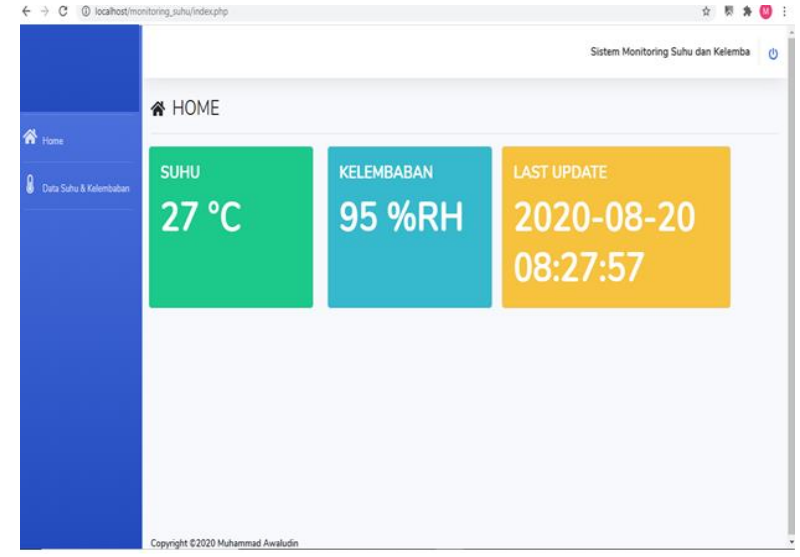

Gambar 10. Tampilan Home

c. Tampilan Laman Data Suhu dan Kelembaban

Dibawah merupakan tampilan halaman rincian riwayat data suhu dan kelembaban udara berdasarkan 50 data terakhir yang ditampilkan secara rinci dimana data tersebut merupakan data yang tersimpan di dalam database. Tampilan laman data suhu dan kelembaban disajikan pada Gambar 11. 
(c) Andi Yusika Rangan, Amelia Yusnita, Muhammad Awaludin

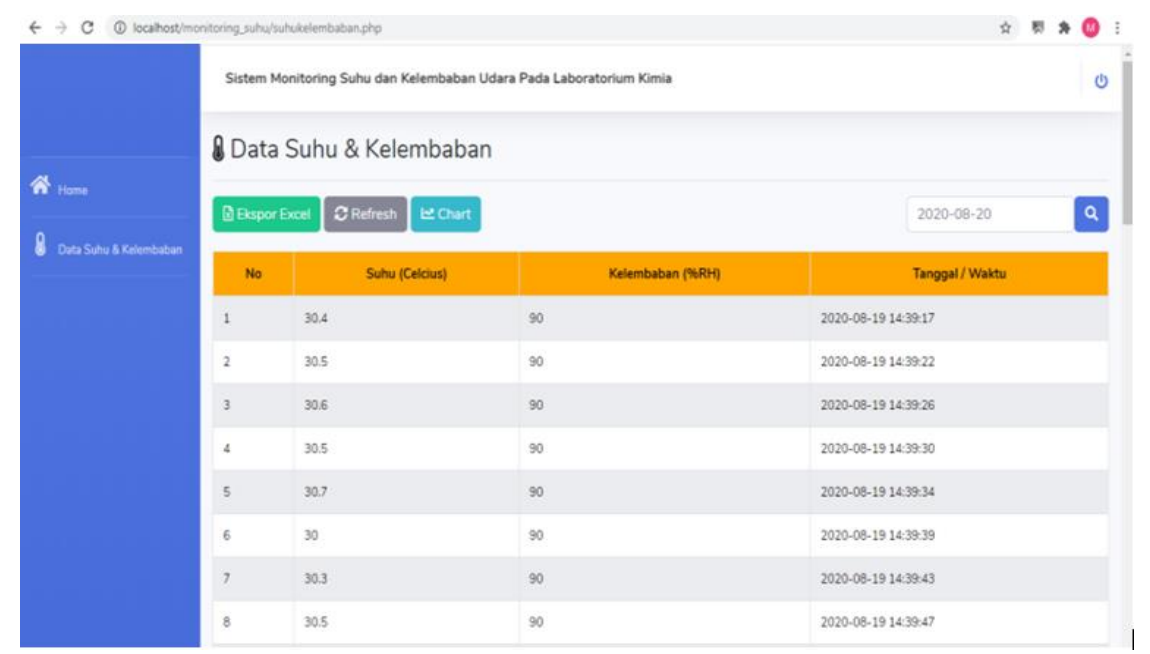

Gambar 11. Tampilan Laman Data Suhu dan Kelembaban

d. Tampilan Halaman Chart

Dibawah merupakan tampilan halaman chart atau grafik suhu dan kelembaban udara pada laboratorium kimia berdasarkan 50 data terakhir yang disajikan pada Gambar 12 dan Gambar 13.

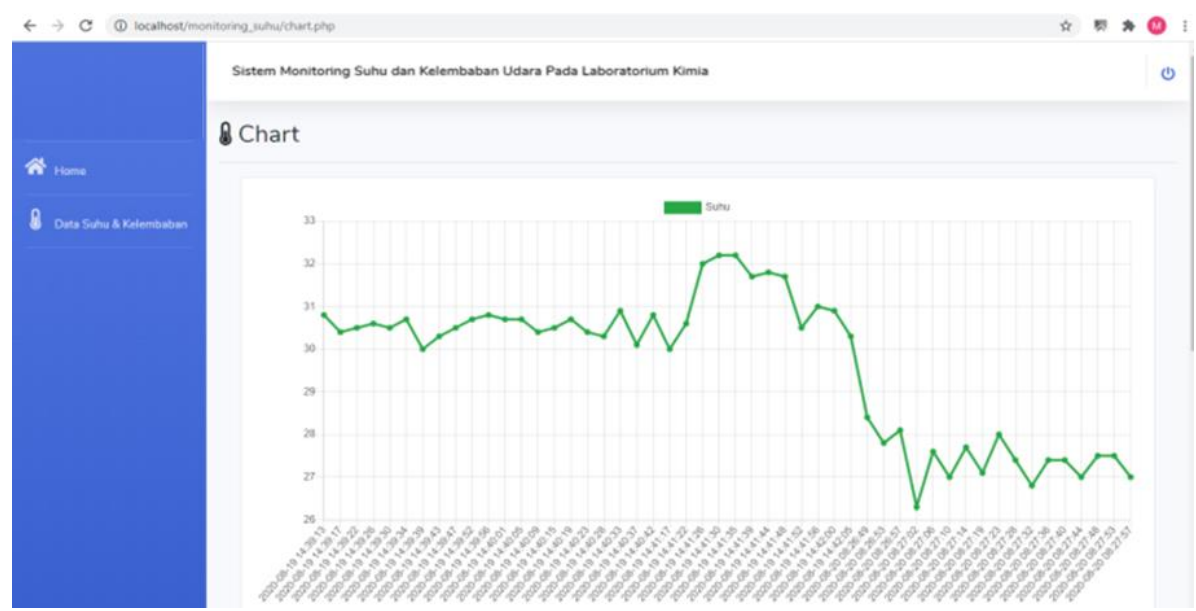

Gambar 12. Tampilan Chart Data Suhu

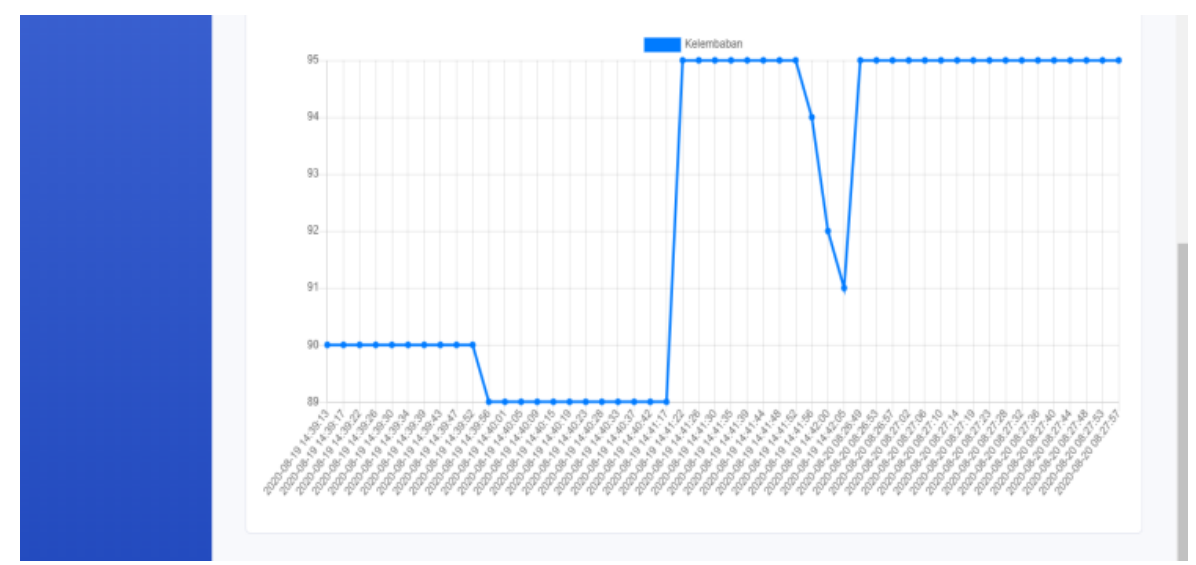

Gambar 13. Tampilan Chart Data Kelembaban 


\subsection{Uji coba}

a. Pengujian Hardware

Memapilkan hasil Pengujian sensor suhu dan kelembaban udara menggunakan DHT11 ini bertujuan untuk mengetahui akurasi dari pembacaan suhu dan kelembaban udara sensor DHT11. Hasil pengujian suhu pada sensor DHT11 dan Thermometer disajikan pada Tabel 3.

Tabel 3. Hasil pengujian suhu pada sensor DHT11 dan Thermometer

\begin{tabular}{cccc}
\hline No & DHT11 (Suhu) & Thermometer & Error $\left({ }^{\circ} \mathbf{C}\right)$ \\
\hline 1. & 24,0 & 25,0 & 1 \\
\hline 2. & 24,9 & 26,0 & 1,1 \\
\hline 3 & 25,2 & 25,5 & 0,3 \\
\hline 4. & 25,4 & 25,9 & 0,5 \\
\hline 5. & 25,7 & 25,9 & 0,2 \\
\hline
\end{tabular}

Hasil pengujian kelembaban pada sensor DHT11 dan Hygrometer disajikan pada Tabel 4.

Tabel 4. Hasil pengujian kelembaban pada sensor DHT11 dan Hygrometer

\begin{tabular}{cccc}
\hline No & DHT11 (Kelembaban) & Hygrometer & Error $(\mathbf{\%} \mathbf{R})$ \\
\hline 1. & 51 & 53 & 2 \\
\hline 2. & 51 & 55 & 4 \\
\hline 3 & 55 & 58 & 3 \\
\hline 4. & 62 & 63 & 1 \\
\hline 5. & 63 & 63 & 0 \\
\hline
\end{tabular}

Menapilkan hasil Pengujian kipas fan (pendingin) ini bertujuan untuk mengetahui apakah kipas fan berfungsi sesuai dengan apa yang telah diprogramkan sebelumnya. Hasil pengujian kipas fan (pendingin) disajikan pada Tabel 5.

Tabel 5. Hasil pengujian kipas fan (pendingin)

\begin{tabular}{ccc}
\hline NO & DHT11 (Suhu) & Kipas Fan \\
\hline 1. & 24,0 & OFF \\
\hline 2. & 24,8 & OFF \\
\hline 3 & 25 & OFF \\
\hline 4. & 25,9 & ON \\
\hline 5. & 26,2 & ON
\end{tabular}

Dari data yang di dapatkan dari tabel di atas, hasil pengukuran suhu yang melebihi 25 derajat celcius akan membuat kondisi pada kipas fan menyala. Jika hasil pengukuran suhu yang kurang dari atau sama dengan 25 derajat celcius akan membuat kondisi kipas fan mati. 
Pengujian terhadap Fungsi dari program LCD menampilkan hasil pengukuran suhu dan kelembaban udara yang di dapat dari pembacaan sensor DHT11 yang telah di proses oleh mikrokontroler NodeMCU ESP8266. Pengujian disini dilakukan ketika sistem dinyalakan maka LCD akan hidup dengan menampilkan informasi suhu dan kelembaban udara pada laboratorium kimia. Pengujian fungsi program LCD disajikan pada Gambar 14.

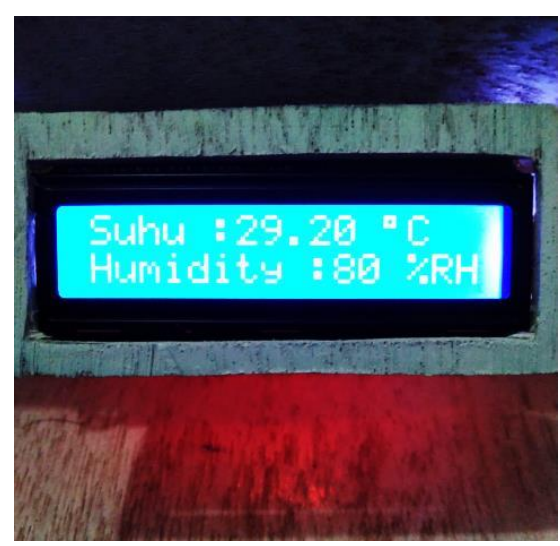

Gambar 14. Pengujian fungsi program LCD

Pada saat pengujian LCD akan memunculkan nilai suhu dan kelembaban udara yang dibaca oleh sensor DHT11 di laboratorium kimia sehingga bila tidak ada koneksi internet yang mana tidak memungkinkan memonitoring lewat website, maka monitoring tetap dapat dilakukan lewat LCD

\section{b. Pengujian white-box}

Pengujian pada alat monitoring suhu dan kelembaban udara pada laboratorium kimia meliputi beberapa modul. Pengujian meliputi listing program, jenis pengujian, hasil yang diharapkan, dan hasil pengujian. Modul yang diuji adalah sebagai berikut: Penujian White-box disajikan pada Tabel 6.

Tabel 6. Penujian White-box

\begin{tabular}{llll}
\hline No & \multicolumn{1}{c}{ Uraian } & \multicolumn{1}{c}{ Kode Program } & \multicolumn{1}{c}{ Keterangan } \\
\hline 1. & Mengkoneks & //include library ESP8266 & Berhasil terhubung ke \\
ikan & \#include <ESP8266HTTPClient.h> server \\
NodeMCU & \#include <ESP8266WiFi.h> \\
ESP8266 ke & /setting jaringan \\
jaringan & const char* ssid = "WELLND"; \\
WiFi & const char* password = "wel12345"; \\
& const char* host = "192.168.43.28"; //setting koneksi \\
& wifi \\
& WiFi.hostname("InternetOfThings"); \\
& WiFi.begin(ssid, password); \\
& //apabila berhasil terkoneksi \\
& //tampilkan pesan di serial Wifi connected \\
& Serial.println("WiFi Connected"); \\
\hline
\end{tabular}




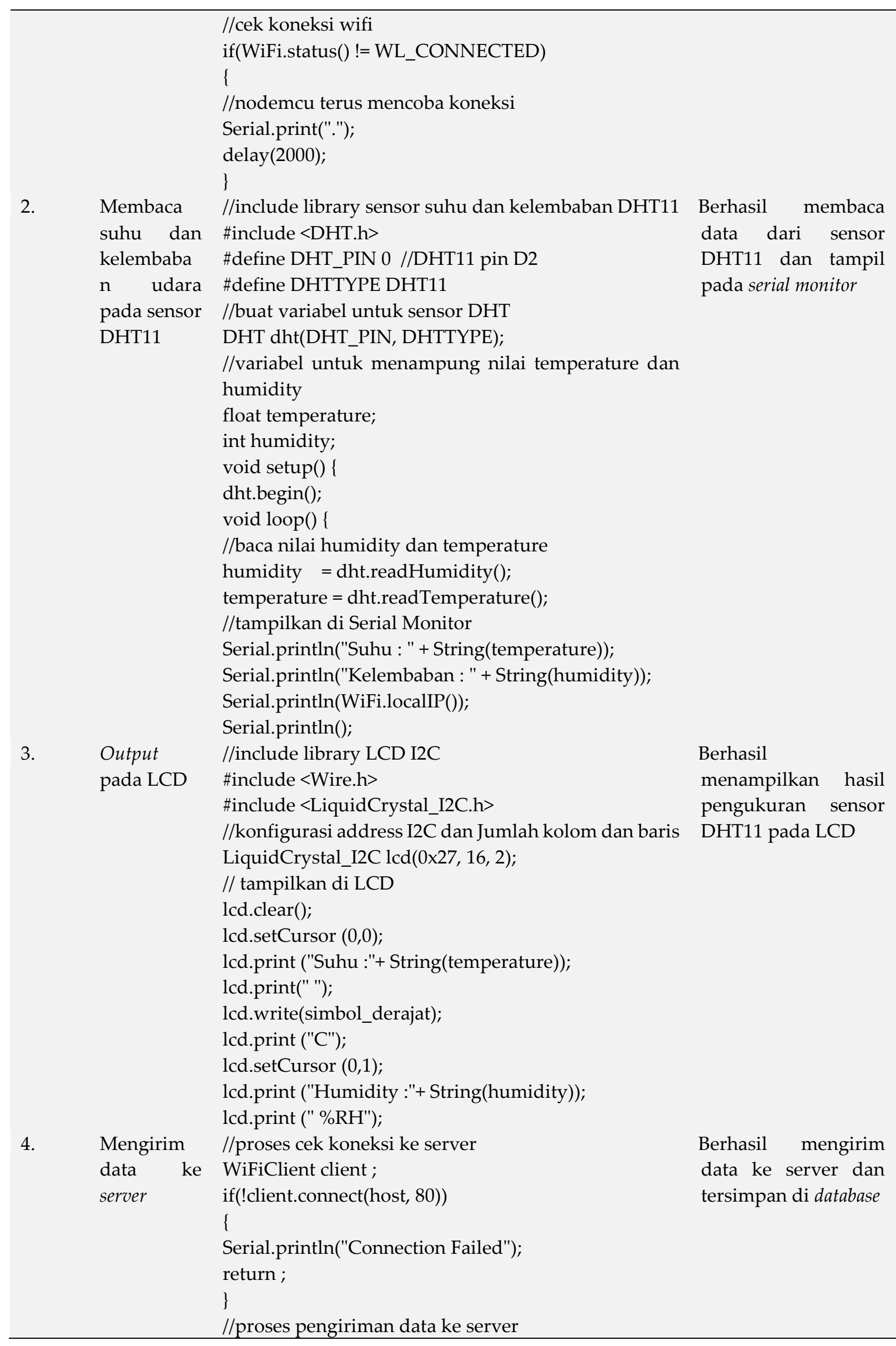




\begin{tabular}{|c|c|c|c|}
\hline 5. & $\begin{array}{l}\text { Modul } \\
\text { Relay dan } \\
\text { Kipas Fan }\end{array}$ & $\begin{array}{l}\text { String Link; } \\
\text { HTTPClient http; } \\
\text { Link } \\
\text { "http://"+String(host)+"/monitoring_suhu/kirimdata.p } \\
\text { hp?temp=" + String(temperature) + "\&kelembaban=" + } \\
\text { String(humidity); } \\
\text { //eksekusi link } \\
\text { http.begin(Link); } \\
\text { //mode GET } \\
\text { http.GET(); } \\
\text { http.end(); } \\
\text { delay(4000); } \\
\text { \#define RELAY 2 //Relay pin D4 } \\
\text { pinMode(RELAY, OUTPUT); } \\
\text { digitalWrite (RELAY,HIGH); } \\
\text { //kondisi kipas menyala saat suhu ruangan diatas } 25 \\
\text { derajat celcius } \\
\text { if (temperature >25 )\{ } \\
\text { digitalWrite (RELAY,LOW); } \\
\text { \} } \\
\text { else\{ } \\
\text { digitalWrite (RELAY,HIGH); } \\
\text { \} }\end{array}$ & $\begin{array}{lr}\text { Berhasil menyalakan } \\
\text { kipas ketika suhu } \\
\text { lebih dari } 25 \text { derajat } \\
\text { celcius dan kipas } \\
\text { mati ketika suhu } \\
\text { kurang dari } 25 \\
\text { derajat celcius }\end{array}$ \\
\hline
\end{tabular}

\section{KESIMPULAN}

Untuk membuat alat monitoring suhu dan kelembaban udara pada laboratorium kimia yang berbasis Internetof Things (IoT) dibutuhkan komponen utama yaitu, NodeMCU ESP8266 sebagai mikrokontroler yang melakukan proses data hingga menghasilkan output, sensor DHT11 sebagai input suhu dan kelembaban udara, LCD 16x2 sebagai tampilan output, relay sebagai saklar yang menghubungankan kipas fan, kipas fan sebagai perangkat keras untuk pendingin ruangan. Berdasarkan hasil pengujian sistem monitoringsuhu dan kelembaban udara dapat berfungsi dengan baik. diharapkan sistem ini juga bisa dikombinasikan dengan komponen lain seperti messenger untuk notifikasi langsung ke pengguna yang bertangung jawab langsung jika ada faktor-faktor yang mebahayakan laboratorium.

\section{REFERENSI}

[1] T. Erlina, "Sistem Monitoring Suhu, Kelembaban Dan Gas Amonia Pada Kandang Sapi Perah Berbasis Teknologi Internet of Things (Iot)," J. Inf. Technol. Comput. Eng., vol. 1, no. 01, pp. 1-7, 2017, doi: 10.25077/jitce.1.01.1-7.2017.

[2] D. Wijanarko and S. Hasanah, "Monitoring Suhu Dan Kelembaban Menggunakan Sms Gateway Pada Proses Fermentasi Tempe Secara Otomatis Berbasis Mikrokontroler," J. 
Inform. Polinema, vol. 4, no. 1, p. 49, 2017, doi: 10.33795/jip.v4i1.144.

[3] A. R. Hakim, B. Harpad, T. Informatika, and T. Informatika, "SISTEM MONITORING SUHU LABORATORIUM KOMPUTER," pp. 1-6, 2010.

[4] K. Apriliya, "Sistem Pemantauan Suhu dan Kelembaban Inkubator Telur Melalui Jaringan Global System for Mobile Comunication Berbasis Short Message Service." Fakultas Teknik, 2016.

[5] G. J. Ohara and S. T. T. TELKOM, “Aplikasi Sistem Monitoring Berbasis Web Untuk Open Cluster," Bdg. Sekol. Tinggi Teknol. TELKOM, 2005.

[6] F. Xia, L. T. Yang, L. Wang, and A. Vinel, "Internet of things," Int. J. Commun. Syst., vol. 25, no. 9, p. 1101, 2012.

[7] A. W. Burange and H. D. Misalkar, "Review of Internet of Things in development of smart cities with data management \& privacy," in 2015 International Conference on Advances in Computer Engineering and Applications, 2015, pp. 189-195.

[8] I. Amanah, “Identifikasi Bahaya Dan Penilaian Risiko (Risk Assessment) di Laboratorium Studi Kasus di Laboratorium Lingkungan Fakultas Teknik Universitas Diponegoro." Universitas Diponegoro, 2011.

[9] E. Nurmiati, "Analisis dan perancangan web server pada handphone," Stud. Inform. J. Sist. Inf., vol. 5, no. 2, 2012.

[10] P. M. Ogedebe and B. P. Jacob, "Software Prototyping: A Strategy to Use When User Lacks Data Processing Experience," ARPN J. Syst. Softw., vol. 2, no. 6, pp. 219-224, 2012. 